\title{
MELATIH KECERDASAN KOGNITIF, AFEKTIF, DAN PSIKOMOTORIK ANAK SEKOLAH DASAR MELALUI PERANCANGAN GAME SIMULASI "WARUNGKU"
}

\author{
Toto Haryadi ${ }^{1}$, Aripin ${ }^{2}$ \\ ${ }^{1,2}$ Program Studi Desain Komunikasi Visual \\ Fakultas Ilmu Komputer, Universitas Dian Nuswantoro \\ haryadi.dinus@gmail.com ${ }^{1}$, arifin@dosen.dinus.ac.id ${ }^{2}$
}

\begin{abstract}
Abstrak
Pendidikan merupakan kebutuhan primer bagi setiap manusia guna menjalani hidup agar selaras dengan tujuan dan cita-cita. Pintu gerbang awal untuk memperoleh pendidikan dimulai dari sekolah dasar, sebagai institusi formal yang berkewajiban membekali anak dengan multi intelegensi sesuai dengan kurikulum yang dibakukan. Semakin maju dan kompleksnya dunia pendidikan khususnya tingkat sekolah dasar (SD), telah menciptakan paradigma bahwa keberhasilan anak hanya ditentukan secara akademis yang diukur melalui kecerdasan kognitif berdasarkan angka rapor maupun hasil tes Intelligence Quotient (IQ). Padahal, dalam kehidupan sehari-hari anak juga perlu mengembangkan kecerdasan afektif dan psikomotorik, guna mengimbangi kemampuan anak dalam memahami sesuatu secara teori dan praktik. Salah satu cara untuk mengembangkan kecerdasan afektif dan psikomotorik anak tanpa meninggalkan kemampuan kognitif yaitu melalui kegiatan bermain, atau juga bisa diwujudkan dalam bentuk permainan (baik tradisional maupun digital). Kemajuan teknologi yang ditunjukkan dengan maraknya perangkat digital khususnya komputer, laptop, komputer tablet, hingga smartphone, bisa dimanfaatkan untuk mengeksplorasi tiga kecerdasan di atas. Tanpa harus berkutat di institusi pendidikan formal, orang tua maupun guru bisa membuat media yang mengajak anak belajar sambil bermain. Dengan memanfaatkan konten lokal berupa makanan khas Jawa Tengah, game "Warungku" bisa menjadi salah satu media alternatif guna melatih kecerdasan kognitif, afektif, dan psikomotorik.
\end{abstract}

Kata Kunci: kecerdasan, kognitif, afektif, psikomotorik, game simulasi

\section{PENDAHULUAN}

Sebagai bagian dari tahap pertumbuhan dan perkembangan manusia menuju dewasa, fase anak-anak memiliki keistimewaan tersendiri yang dikenal dengan masa keemasan atau golden age[1], yaitu masa terbentuknya pondasi sikap, perilaku, mental, serta kecerdasan (spiritual, intelektual, emosional, kinestetik, seni, dan sosial) yang semuanya terjadi secara intensif[2]. Keistimewaan tersebut sudah mulai dipahami oleh sebagian besar guru dan orang tua yang saling bekerja sama untuk memaksimalkan potensi anak. Khususnya dalam hal kecerdasan, anak-anak terus dilatih untuk menonjolkan kecerdasannya melalui berbagai cara.

Dari berbagai kecerdasan di atas, guru dan orang tua cenderung fokus pada kecerdasan intelektual. Anak diwajibkan mengikuti program pendidikan formal tingkat Sekolah Dasar (SD), sebagai langkah awal program wajib belajar 12 tahun. Orang tua mendukung dengan memfasilitasinya. Jika intensitas dan kualitas pendidikan anak di sekolah dirasa kurang, orang tua menambahkan les privat. Di satu sisi, upaya tersebut 
dianggap tepat demi masa depan anak. Namun di sisi lain, muncul paradigma bahwa keberhasilan anak SD sangat ditentukan oleh intelektual yang mengarah ke ranah kognitif dan tes intelegensi (Lucy, 2009:5). Hal ini diperkuat dengan ketentuan dari sekolah yang masih menerapkan sistem pendidikan konvensional, dengan kurikulum yang menitikberatkan pada ranah kognitif $90 \%$ dan afektif hanya $10 \%[3]$.

Kecerdasan afektif dan psikomotorik cenderung diabaikan[4]. Meskipun memiliki kapabilitas sempurna di bidang kognitif, anak belum bisa dikatakan sebagia manusia utuh jika tidak memiliki kecerdasan afektif dan psikomotorik. Hal ini juga belum banyak disadari oleh guru dan orang tua. Padahal, anak juga membutuhkan kedua kecerdasan di atas untuk menyeimbangkan fungsi otak kiri dan kanan, yang sebenarnya bisa diwujudkan dalam bentuk permainan. Melalui permainan, anak bisa memperoleh berbagai nilai sekaligus mengembangkan imajinasi dan kreativitasnya[5].

Kemajuan teknologi yang ditandai dengan lahirnya produk canggih seperti: komputer, laptop, komputer tablet, hingga smartphone, telah merambah ke bidang pendidikan. Dengan memadukan sistem edukasi dan kemajuan teknologi tersebut, penulis membuat satu alternatif pemecahan masalah, paradigma, serta fenomena di atas dengan merancang game simulasi "Warungku" yang ditujukan kepada anak sekolah dasar, guna mengeksplorasi tiga kecerdasan: kognitif, afektif, serta psikomotorik.

\section{TINJAUAN PUSTAKA}

\subsection{Kecerdasan}

Dari banyak ahli yang membicarakan tentang kecerdasan, dua di antaranya yaitu Gardner dan Bunda Lucy. Gardner (Hardywinoto dan Setiabudhi, 2003:52) menjelaskan bahwa kecerdasan merupakan kemampuan seseorang yang pada dasarnya digunakan untuk pemecahan masalah atau menciptakan produk berdaya guna yang bisa diterima masyarakat. Pemaknaan tersebut kemudian lebih diperjelas lagi bahwa setiap orang terlahir dengan kecerdasan yang berbeda baik pola maupun tingkatannya, yang didasari pada pembagian kecerdasan menjadi tujuh bidang, yakni: kecerdasan bahasa, logis-matematik, spasial, kecerdasan musik, kecerdasan kinestetik, kecedasan intrapersonal; serta kecerdasan interpersonal. Kecerdasan yang dimiliki seorang anak tidak bersifat mutlak. Hal ini disebabkan adanya aspek nature sekaligus nurture (Lucy, 2009:5). Nature berarti bahwa kecerdasan itu diwariskan (hereditas). Seiring waktu kecerdasan bisa berubah ke arah baik atau buruk, tergantung keterlibatan stimulasi dan masukan dari lingkungan sekitar (nurture).

Setiap anak memiliki lebih dari satu jenis kecerdasan yang terwujud pada suatu tindakan yang menjadi ciri khas. Sebagai contoh, anak yang mahir bermain piano memiliki kecerdasan musik dan kinestetik sekaligus. Sebaliknya mahir dalam menyelesaikan soal cerita tentang aritmatika, maka kecerdasan bahasa dan logismatematik yang terlibat. Kecerdasan ini memiliki orientasi yang sama yakni keduanya dipengaruhi fungsi otak kiri, karena numerik dan verbal diolah oleh otak kiri. Sebaliknya, kecerdasan musik memiliki orientasi ke otak kanan yang mengolah unsur kreativitas. Untuk lebih jelasnya bisa dilihat pada gambar berikut. 


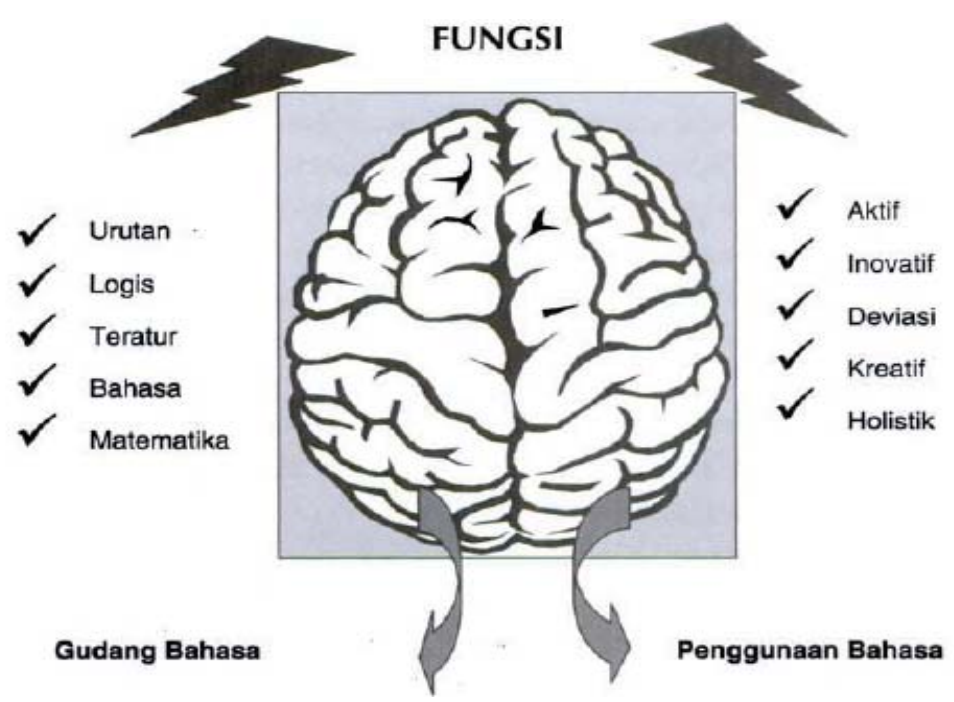

Gambar 1. Fungsi Otak Kiri dan Kanan

[Sumber: Williams dalam Harsanto (2007: 37)]

\subsubsection{Kognitif}

Kognitif merupakan suatu pokok bahasan yang berhubungan dengan kognisi, dengan tujuan akhir berupa pengetahuan yang didapat melalui percobaan, penelitian, penemuan, dan pengamatan. Pengetahuan yang diperoleh harus sesuai dengan fakta (faktual) dan pengalaman yang telah dilakukan (empiris)[6], sehingga bisa dibuktikan kebenarannya. Kognitif berhubungan erat dengan pikiran, memori, nalar, intelektual, kemampuan berhitung, logika, eksakta, sains, numerik, dan akademik.

Sistem pendidikan di Indonesia telah menempatkan kognitif sebagai aspek penting bagi siswa. Hal ini tampak pada kurikulum sekolah masih menempatkan kognitif sebagai sesuatu yang wajib dikuasai. Orang tua akan melakukan apapun untuk mendorong anaknya menjadi manusia yang cerdas, supaya bisa berprestasi secara akademik. Anak diharuskan memiliki kemampuan yang kuat dalam hal logika dan bahasa/verbal. Dalam kasus pendidikan di Indonesia, sebagian besar orang tua berharap anaknya yang masih duduk di sekolah dasar memiliki kemampuan berbahasa Inggris yang bagus. Untuk mewujudkan ambisi tersebut, anak diharuskan mengikuti les privat bahasa Inggris guna menambah jam belajar. Di sini bukan berarti anak-anak dilarang mempelajari bahasa Inggris, namun yang perlu diperhatikan adalah kesesuaian kapasitas otak dengan materi yang diajarkan. Untuk mengasah kemampuan tersebut tidak harus mempelajari bahasa asing, karena Indonesia juga memiliki bahasa induk yang memiliki kajian sangat banyak untuk dijadikan bahan pembelajaran. Lebih jauh lagi, Mager, Gronlund, dan Bloom (Harsanto, 2007: 95) merumuskan bahwa setiap kecerdasan memiliki domain yang berbeda. Khusus kognitif terdapat enam domain yakni sebagai berikut: 
Tabel 1. Domain kognitif beserta contoh penerapannya

[Sumber: Harsanto (2007: 95-98)]

\begin{tabular}{|c|c|c|}
\hline Domain & Deskripsi & Implementasi dalam pembelajaran \\
\hline Pengetahuan & $\begin{array}{l}\text { Pengetahuan atas fakta, definisi, } \\
\text { nama, peristwa, teori, dan } \\
\text { kesimpulan }\end{array}$ & $\begin{array}{l}\text { Mengemukakan arti, mengindentifikasi, } \\
\text { mendeskripsikan sesuatu, menguraikan } \\
\text { apa yang terjadi }\end{array}$ \\
\hline Pemahaman & $\begin{array}{l}\text { Pengertian atas hubungan antar } \\
\text { faktor, konsep data, sebab- } \\
\text { akibat, dan penarikan kesimpulan }\end{array}$ & $\begin{array}{l}\text { Membedakan dan membandingkan, } \\
\text { menginterpretasi data, } \\
\text { mengonversikan, memberi contoh }\end{array}$ \\
\hline Aplikasi & $\begin{array}{l}\text { Menggunakan pengetahuan } \\
\text { untuk solusi masalah dan } \\
\text { implementasi }\end{array}$ & $\begin{array}{l}\text { Menghitung, melakukan percobaan, } \\
\text { memodifikasi, memprediksi }\end{array}$ \\
\hline Analisis & $\begin{array}{l}\text { Menentukan bagian masalah, } \\
\text { penyelesaian, dan menunjukkan } \\
\text { hubungan antar bagian }\end{array}$ & $\begin{array}{l}\text { Mengidentifikasi faktor penyebab, } \\
\text { merumuskan masalah, membuat grafik, } \\
\text { menggambarkan }\end{array}$ \\
\hline Sintesis & $\begin{array}{l}\text { Menggabungkan informasi } \\
\text { menjadi kesimpulan atau konsep; } \\
\text { dan menciptakan hal baru } \\
\text { dengan mengolah berbagai ide }\end{array}$ & $\begin{array}{l}\text { Membuat desain, menciptakan produk } \\
\text { baru, merancang model dan } \\
\text { mengategorikan }\end{array}$ \\
\hline Evaluasi & $\begin{array}{l}\text { Mempertimbangkan suatu hal } \\
\text { berdasarkan oposisi biner (benar- } \\
\text { salah, baik-buruk, dan lain-lain) }\end{array}$ & $\begin{array}{l}\text { Beradu argumentasi, memilih solusi } \\
\text { yang lebih baik, megadakan } \\
\text { perbandingan, memberi kesimpulan }\end{array}$ \\
\hline
\end{tabular}

\subsubsection{Afektif}

Afektif memiliki cakupan yang berbeda dengan kognitif, karena lebih berhubungan dengan psikis, jiwa, dan rasa. Secara lebih detail, kecerdasan ini meliputi sikap (menikmati, menghormati), penghargaan (reward, hukuman), nilai (moral, sosial), dan emosi (sedih, senang). Pembentukan karakter diri dan sikap cocok diajarkan sejak masa anak-anak. Hal ini bisa dilakukan oleh orang tua di rumah maupun guru di sekolah. Diiringi dengan berkembangnya kecerdasan kognitif, anak juga perlu dilatih mengembangkan afektif. Anak tidak hanya didorong untuk pintar, tetapi juga aktif, bertingkah laku baik, berakhlak mulia, dan sebagainya.

Kenyataan yang ada, kecenderungan Sekolah Dasar di Indonesia belum mengeksplorasi kecerdasan afektif secara maksimal, yakni hanya $10 \%$ di dalam kurikulum pendidikan. Kecilnya angka tersebut memberikan paradigma bahwa afektif kurang mendukung sistem pembelajaran. Meskipun Pemerintah telah melakukan revisi kurikulum mulai tahun 1947 hingga 2013 dengan berbagai penambahan sesuai dengan kebutuhan dan perkembangan IPTEK[7], penambahan aspek afektif ke dalam evaluasi hasil belajar baru dipraktikkan tahun 2004 yang terkenal dengan istilah "Kurikulum Berbasis Kompetensi" atau KBK.

Ditinjau dari perubahannya, KBK tidak lagi berorientasi pada proses belajar, tetapi lebih ke arah kompetensi yang mencakup perpaduan pengetahuan, ketrampilan, sikap, dan nilai. Perpaduan tersebut direfleksikan dalam proses kognitif (berpikir) dan psikomotorik (bertindak). Kompetensi tidak hanya mengembangkan knowledge, tetapi juga understanding, skill, value, attitude, dan interest (Anonim, 2011:102). Selain aspek 
knowledge dan skill di atas, semuanya termasuk dalam wilayah afektif. Sama halnya dengan kognitif, afektif juga memiliki ranah sebagaimana telah dirumuskan oleh Mager, Gronlund, dan Bloom dalam Harsanto (2007: 98-99) yaitu sebagai berikut:

Tabel 2. Domain afektif beserta contoh penerapannya

[Sumber: Harsanto (2007: 98-99)]

\begin{tabular}{|c|l|l|}
\hline Domain & \multicolumn{1}{|c|}{ Deskripsi } & \multicolumn{1}{|c|}{ Implementasi dalam pembelajaran } \\
\hline Penerimaan & $\begin{array}{l}\text { Kepekaan diri terhadap fenomena } \\
\text { dan stimuli guna memberikan } \\
\text { perhatian terkontrol }\end{array}$ & $\begin{array}{l}\text { Bertanya, memilih, senang } \\
\text { mendengarkan-membaca- } \\
\text { mengerjakan }\end{array}$ \\
\hline Responsi & $\begin{array}{l}\text { Menunjukkan perhatian secara aktif, } \\
\text { ingin dan puas merespon }\end{array}$ & $\begin{array}{l}\text { Menaati aturan, mengerjakan tugas, } \\
\text { merenungkan }\end{array}$ \\
\hline $\begin{array}{c}\text { Menghayati } \\
\text { nilai }\end{array}$ & $\begin{array}{l}\text { Termotivasi dan berkomitmen untuk } \\
\text { bertindak sesuai nilai yang dianut }\end{array}$ & $\begin{array}{l}\text { Mengapresiasi, menghargai, } \\
\text { bersimpati }\end{array}$ \\
\hline $\begin{array}{c}\text { Mengorgani } \\
\text { sasi }\end{array}$ & $\begin{array}{l}\text { Mengorganisasi, memantapkan, dan } \\
\text { berusaha menemukan hubungan } \\
\text { antara satu nilai dengan nilai lain }\end{array}$ & $\begin{array}{l}\text { Mendukung penegakan disiplin } \\
\text { nasional }\end{array}$ \\
\hline $\begin{array}{c}\text { Karakterisasi } \\
\text { dengan nilai } \\
\text { (satu atau } \\
\text { kompleks) }\end{array}$ & $\begin{array}{l}\text { Menentukan kepribadian dan } \\
\text { tingkah laku sesuai dengan sistem } \\
\text { nilai yang dimiliki atau dianut }\end{array}$ & $\begin{array}{l}\text { Membulatkan tekad untuk } \\
\text { melaksanakan perintah Allah, } \\
\text { menguatkan diri untuk terus hidup } \\
\text { disiplin }\end{array}$ \\
\hline
\end{tabular}

\subsubsection{Psikomotorik}

Dalam Kamus Besar Bahasa Indonesia (2008), psikomotorik diartikan sebagai suatu aktivitas fisik yang berhubungan dengan proses mental dan psikologi. Psikomotorik berkaitan dengan tindakan dan ketrampilan, seperti lari, melompat, melukis, dan sebagainya. Dalam dunia pendidikan, psikomotorik terkandung dalam mata pelajaran praktik. Psikomotorik memiliki korelasi dengan hasil belajar yang dicapai melalui manipulasi otot dan fisik.

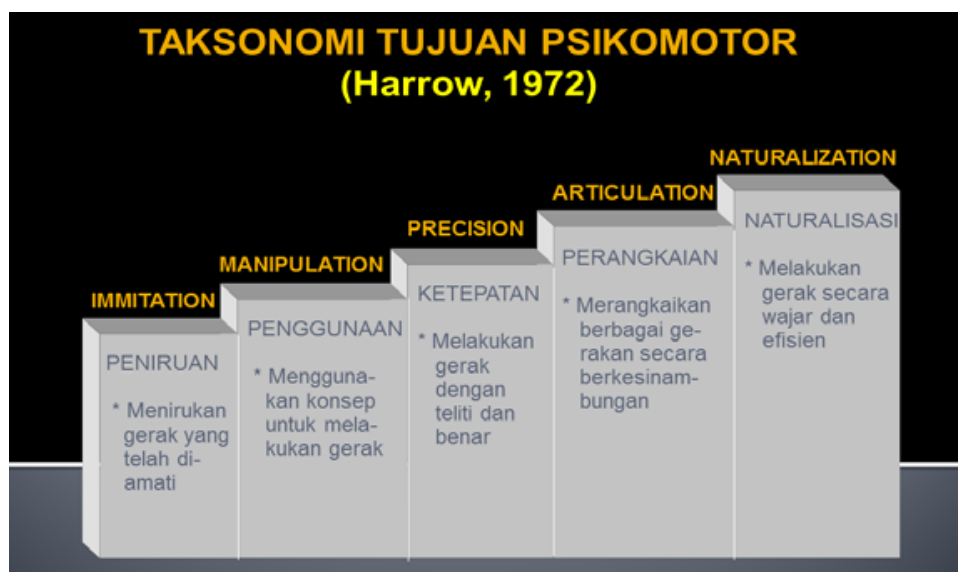

Gambar 2. Domain psikomotorik beserta contoh penerapannya

[Sumber: Sunandar (2011: slide 37)]

Psikomotorik juga memiliki beberapa tingkatan domain, yakni seperti yang ada dalam gambar 2 di atas. Psikomotorik tidak bisa dipisahkan dari kognitif dan afektif. Sebaliknya, psikomotorik juga tidak bisa berdiri sendiri. Setiap apa yang diberikan guru 
kepada siswa perlu dipahami kemudian diterapkan. Proses belajar dimulai dari tahap kognitif (berpikir), kemudian afektif (bersikap), baru psikomotorik (berbuat). Meskipun kognitif dan afektif kini mulai dipisahkan, keduanya masih tetap mengandung psikomotorik. Sebagai contoh, ketergantungan kognitif terhadap psikomotorik tampak pada implementasi ilmu fisika yang diterapkan dalam suatu eksperimen. Afektif yang bergantung pada psikomotorik juga bisa ditemukan dalam pelajaran Agama misalnya praktik tata cara sholat dan berdoa.

\subsection{Anak Sekolah Dasar}

Program Wajib Belajar 9 tahun yang kemudian direvisi menjadi 12 tahun dimulai dari tingkat Sekolah Dasar. Hal ini didasarkan pada pertimbangan bahwa usia anak-anak mengalami pertumbuhan dan perkembangan yang cukup pesat, sehingga siap mengikuti kegiatan belajar secara formal. Menurut Santrock (2003: 26), siswa Sekolah Dasar termasuk dalam masa anak tengah dan akhir (Middle and late childhood), yakni masa perkembangan di usia 6-11 tahun dengan ciri siswa mulai menguasai ketrampilan dasar baca, tulis, dan hitung serta pengenalan budaya. Ketrampilan tersebut diperoleh di lingkungan rumah, yang akhirnya membantu proses pembentukan perilaku anak melalui penguatan verbal, keteladanan, dan identifikasi.

Meskipun anak di usia Sekolah Dasar mengalami banyak perkembangan, bukan berarti pikiran dan jiwanya sudah stabil. Erikson dalam Santrock (2003: 48) menamai tahapan usia tersebut dengan istilah "Industry vs Inferiority" yang memiliki karakteristik perluasan imajinasi dan antusias. Anak-anak mengarahkan energinya untuk menguasai pengetahuan dan ketrampilan intelektual, namun masih dibarengi perasaan tidak kompeten dan tidak produktif.

\subsection{Game Simulasi}

Istilah game (permainan) memiliki arti: (1) (mainan) alat untuk bermain; barang atau sesuatu yang dipermainkan; (2) pertunjukan, tontonan, (3) tindakan bermain..... (KBBI, 2008: 968). Dalam kamus yang sama, simulasi berarti metode pelatihan yang memperagakan sesuatu dalam bentuk tiruan; penggambaran suatu sistem atau proses dengan peragaan berupa model statistik dan pemeranan. Jadi, secara harfiah, game simulasi yaitu permainan atau alat bermain yang memperagakan suatu sistem atau proses. Game ini biasa digunakan untuk training (latihan) dalam bidang tertentu.

Game simulasi semakin dibutuhkan dalam berbagai hal. Beberapa bidang penting yang menggunakan game jenis ini yaitu: militer, penerbangan, kesehatan, dan pendidikan. Dilihat dari bidang-bidang tersebut, tujuan sebenarnya game simulasi dibuat yaitu untuk mengurangi biaya, risiko, efisiensi tempat dan waktu, serta efektivitas kerja. Selain hal penting di atas, banyak game simulasi yang hadir sebagai media latihan melakukan pekerjaan sehari-hari. Di Indonesia hadir game Cooking Acedemy (memasak), Oek-Oek (merawat bayi), Ahli Rambut (menata rambut), Cute Pet Hospital (merawat binatang), dan masih banyak yang lain. 


\section{METODE ANALISIS DAN PERANCANGAN}

\subsection{Metode Analisis Masalah}

Analisis ini dilakukan menggunakan metode Framing, yakni menganalisis pokok masalah tentang pendidikan dan game, dengan merumuskan realita yang terjadi di lapangan, mencari kondisi ideal dari permasalahan tersebut, menentukan penyebab ketimpangan antara realita dan ideal, lalu membuat statement sebagai kesimpulan.

Tabel 3. Analisis Data Melalui Metode Framing

\begin{tabular}{|l|l|l|l|}
\hline \multicolumn{1}{|c|}{ Realita } & \multicolumn{1}{|c|}{ Ideal } & \multicolumn{1}{c|}{ Penyebab } & \multicolumn{1}{c|}{ Statement } \\
\hline $\begin{array}{l}\text { Anak yang dianggap } \\
\text { pandai adalah anak } \\
\text { yang mendapat } \\
\text { rangking 1-3 besar } \\
\text { di sekolah }\end{array}$ & $\begin{array}{l}\text { Pandai tidaknya } \\
\text { seorang anak tidak } \\
\text { harus diukur dengan } \\
\text { nilai hasil ulangan } \\
\text { dan rapor }\end{array}$ & $\begin{array}{l}\text { Paradigma di } \\
\text { masyarakat bahwa } \\
\text { prestasi hanya } \\
\text { ditentukan oleh } \\
\text { rangking }\end{array}$ & $\begin{array}{l}\text { Pelajari aspek lain } \\
\text { yang bisa menjadi } \\
\text { tolak ukur } \\
\text { kecerdasan anak- } \\
\text { anak }\end{array}$ \\
\hline $\begin{array}{l}\text { Orang tua } \\
\text { menyuruh anak } \\
\text { belajar setiap waktu } \\
\text { sepanjang hari }\end{array}$ & $\begin{array}{l}\text { Waktu belajar bagi } \\
\text { anak harus } \\
\text { proporsional dengan } \\
\text { kemampuannya }\end{array}$ & $\begin{array}{l}\text { Obsesi orang tua } \\
\text { terhadap anaknya } \\
\text { agar selalu mendapat } \\
\text { nilai bagus di sekolah }\end{array}$ & $\begin{array}{l}\text { Pahami karakteristik } \\
\text { masing-masing anak }\end{array}$ \\
\hline $\begin{array}{l}\text { Orang tua } \\
\text { anak bermain game }\end{array}$ & $\begin{array}{l}\text { Anak-anak memiliki } \\
\text { hak untuk } \\
\text { mengeksplorasi } \\
\text { kemampuan dengan } \\
\text { bermain game }\end{array}$ & $\begin{array}{l}\text { Game dianggap } \\
\text { membuat anak-anak } \\
\text { malas belajar }\end{array}$ & $\begin{array}{l}\text { Beri kesempatan } \\
\text { anak untuk } \\
\text { mengeksplorasi } \\
\text { kecerdasan melalui } \\
\text { aktivitas bermain } \\
\text { game sambil belajar }\end{array}$ \\
\hline $\begin{array}{l}\text { Banyak game yang } \\
\text { isinya kurang sesuai } \\
\text { untuk anak }\end{array}$ & $\begin{array}{l}\text { Orang tua perlu } \\
\text { mendampingi anak } \\
\text { ketika bermain game }\end{array}$ & $\begin{array}{l}\text { Kurangnya perhatian } \\
\text { yang diberikan orang } \\
\text { tua untuk anak }\end{array}$ & $\begin{array}{l}\text { Beri pengawasan } \\
\text { kepada anak ketika } \\
\text { bermain game }\end{array}$ \\
\hline
\end{tabular}

Dari analisis framing di atas, statement utama yang akan dijadikan sebagai landasan perancangan game yaitu "beri kesempatan anak untuk mengeksplorasi kecerdasan melalui aktivitas bermain game sambil belajar". Hal ini berarti memberikan kesempatan bagi anak untuk turut mengembangkan kecerdasan kognitif, afektif, dan psikomotorik melalui permainan (khususnya digital), sehingga anak tidak harus selalu belajar secara konvensional. Berdasarkan kalimat pilihan di atas, game simulasi akan dirancang sebagai salah satu upaya untuk mengajak anak-anak bermain sambil belajar.

\subsection{Metode Perancangan Game}

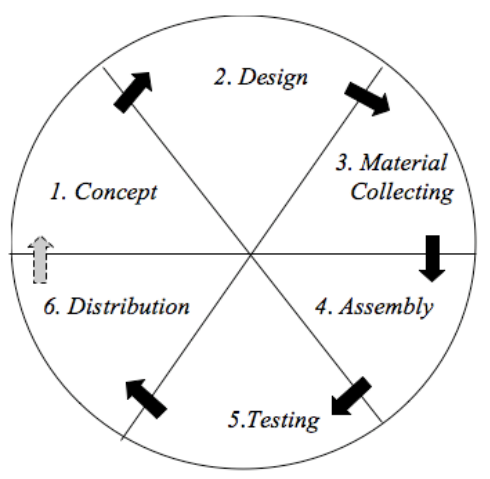

Perancangan game menggunakan Multimedia Development Life Cycle (MDLC). Penggunaan metode ini didasari bahwa game termasuk salah satu produk multimedia. Secara garis besar, perancangan dimulai dari tahap konsep (concept), desain (design), pengumpulan bahan (material collecting), pembuatan (assembly), pengujian (testing), dan rilis (distribution). Informasi lebih detail tentang tiap tahapan bisa dilihat pada tabel berikut:

Gambar 3. Metode Perancangan Multimedia [Sumber: Sutopo (Binanto, 2010: 260)] 
Tabel 4. Proses Perancangan Game Simulasi melalui metode MDLC

\begin{tabular}{|c|c|c|}
\hline Tahapan & Aspek Utama & Keterangan \\
\hline $\begin{array}{l}\text { Concept } \\
\text { (konsep) }\end{array}$ & $\begin{array}{l}\text { Ide pembuatan } \\
\text { Game Simulasi }\end{array}$ & $\begin{array}{l}\text { - Nama game: “Warungku” } \\
\text { (warung merupakan istilah untuk menyebut kios } \\
\text { berjualan jajan, makanan, dan minuman, dan } \\
\text { sebagainya (wilayah Jawa) } \\
\text { - Konten: masakan khas Jawa Tengah } \\
\text { - Tujuan: melatih kognitif, afektif, dan psikomotorik } \\
\quad \text { anak sekolah dasar } \\
\text { Game ini akan dibuat seperti Pizza Frenzy namun dibuat } \\
\text { lebih sederhana menyesuaikan kemampuan anak SD }\end{array}$ \\
\hline $\begin{array}{l}\text { Design } \\
\text { (Desain) }\end{array}$ & $\begin{array}{l}\text { Keseluruhan } \\
\text { kerangka game } \\
\text { yang akan dibuat }\end{array}$ & $\begin{array}{l}\text { - Jenis game: simulasi } \\
\text { - Model permainan: basis klik dan tekan keyboard } \\
\text { - Perangkat: komputer/notebook multimedia } \\
\text { - Tampilan: isometric (proyeksi } 45^{\circ} \text { ) tampak atas } \\
\text { - Sistem levelling: linear (berkelanjutan) }\end{array}$ \\
\hline $\begin{array}{l}\text { Material } \\
\text { Collecting } \\
\text { (pengumpu } \\
\text { lan bahan) }\end{array}$ & $\begin{array}{l}\text { Persiapan } \\
\text { bahan/materi } \\
\text { yang akan } \\
\text { digunakan dalam } \\
\text { pembuatan game }\end{array}$ & $\begin{array}{l}\text { - Aset utama: masakan khas Jawa Tengah } \\
\text { Sampel masakan yang diambil: } \\
\text { Level 1: tengkleng, nasi tengkleng, nasi ayam, } \\
\text { sate ayam, lontong sate ayam } \\
\text { Level 2: menu level } 1 \text { ditambah nasi rawon, } \\
\text { nasi garang asem, nasi goreng ayam, } \\
\text { nasi goreng babat, nasi goreng babat ruwet } \\
\text { level 3: menu level } 2 \text { ditambah nasi pecel, } \\
\text { lontong pecel, lontong campur, tahu gimbal, } \\
\text { dan mie toprak } \\
\text { - Bahan-bahan dasar: bumbu, sayur, dan lauk-pauk } \\
\text { - Karakter utama: seorang anak SD }\end{array}$ \\
\hline $\begin{array}{l}\text { Assembly } \\
\text { (pembuatan) }\end{array}$ & $\begin{array}{l}\text { Membuat desain } \\
\text { dan coding aset } \\
\text { yang digunakan } \\
\text { dalam game }\end{array}$ & $\begin{array}{l}\text { - Desain aset: sayur dan bumbu, perlengkapan dapur, } \\
\text { kemasan makanan, interface dan environment, } \\
\text { navigasi, dan karakter } \\
\text { - desain suara: menyiapkan dan memasang file sound } \\
\text { yang akan digunakan sebagai musik latar dan nada } \\
\text { tombol } \\
\text { - desain sprite: membuat animasi sprite yang } \\
\text { dibutuhkan untuk gerakan semua aset agar tampak } \\
\text { dinamis dan menarik bagi anak sekolah dasar } \\
\text { - coding semua aset yang telah dibuat agar game mulai } \\
\text { bisa dimainkan sesuai konsep yang ditentukan di atas }\end{array}$ \\
\hline $\begin{array}{l}\text { Testing } \\
\text { (pengujian) }\end{array}$ & $\begin{array}{l}\text { Menguji } \\
\text { prototype game } \\
\text { secara alfa } \\
\text { (pembuat game) } \\
\text { dan beta (anak- } \\
\text { anak) }\end{array}$ & $\begin{array}{l}\text { - menguji navigasi yang ada pada tampilan awal } \\
\text { - menguji input nama pemain sebelum masuk level } \\
\text { - menguji gerak karakter utama dan karakter pembeli } \\
\text { - menguji peralatan dan bahan-bahan yang digunakan } \\
\text { untuk memasak: sayur, kompor, kulkas } \\
\text { - menguji sistem reward (pendapatan, skor, bonus, dan } \\
\text { jumlah pemain yang dilayani dengan benar }\end{array}$ \\
\hline Distribusi & $\begin{array}{l}\text { Menyalurkan } \\
\text { game ke target } \\
\text { audiense }\end{array}$ & $\begin{array}{l}\text { - memantau sampel dari anak-anak yang memainkan } \\
\text { game untuk mengetahui apakah gamenya mudah } \\
\text { dipahami atau sebaliknya }\end{array}$ \\
\hline
\end{tabular}




\section{VISUALISASI PERANCANGAN GAME}

Secara garis besar, visualisasi dalam game "Warungku" berbasis vector yang dibuat menggunakan Adobe Flash CS3. Aset yang digunakan dalam game didesain mirip dengan objek sebenarnya, namun menggunakan gaya simplifikasi (penyederhanaan) untuk objek-objek yang memiliki kedetailan cukup rumit.

Tabel 5. Visualisasi aset mencakup sampel bahan-bahan hingga peralatan

\begin{tabular}{|c|c|c|c|c|c|}
\hline Sayur & Daging & Kuah & Lauk & Peralatan & Perkakas besar \\
\hline & & opor & & kompor gas & \\
\hline bayam & sapi & sambal kacang & tahu & wajan & \\
\hline
\end{tabular}
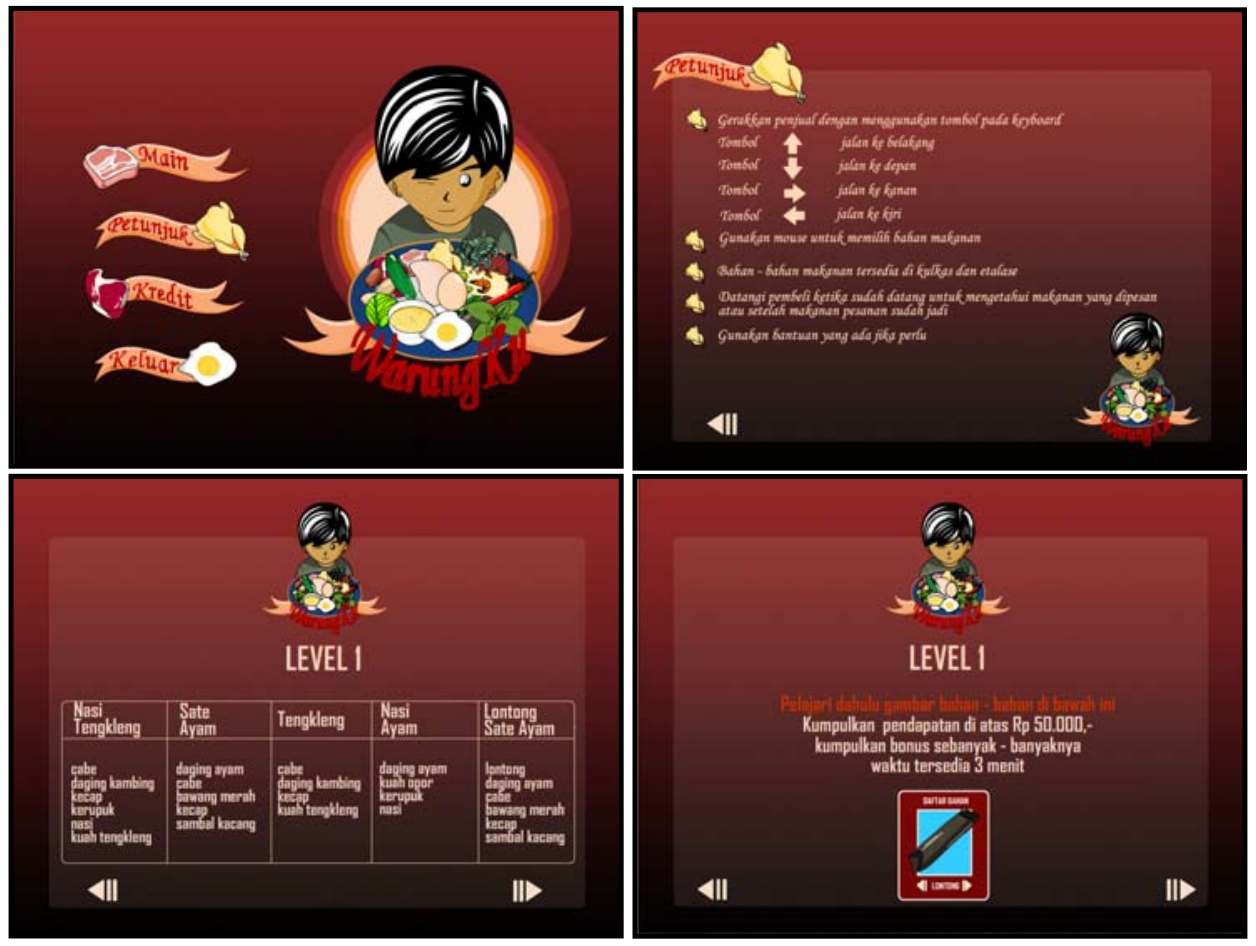

Gambar 4. Tampilan awal game: mulai dari menu utama hingga tugas yang harus dikerjakan pemain 


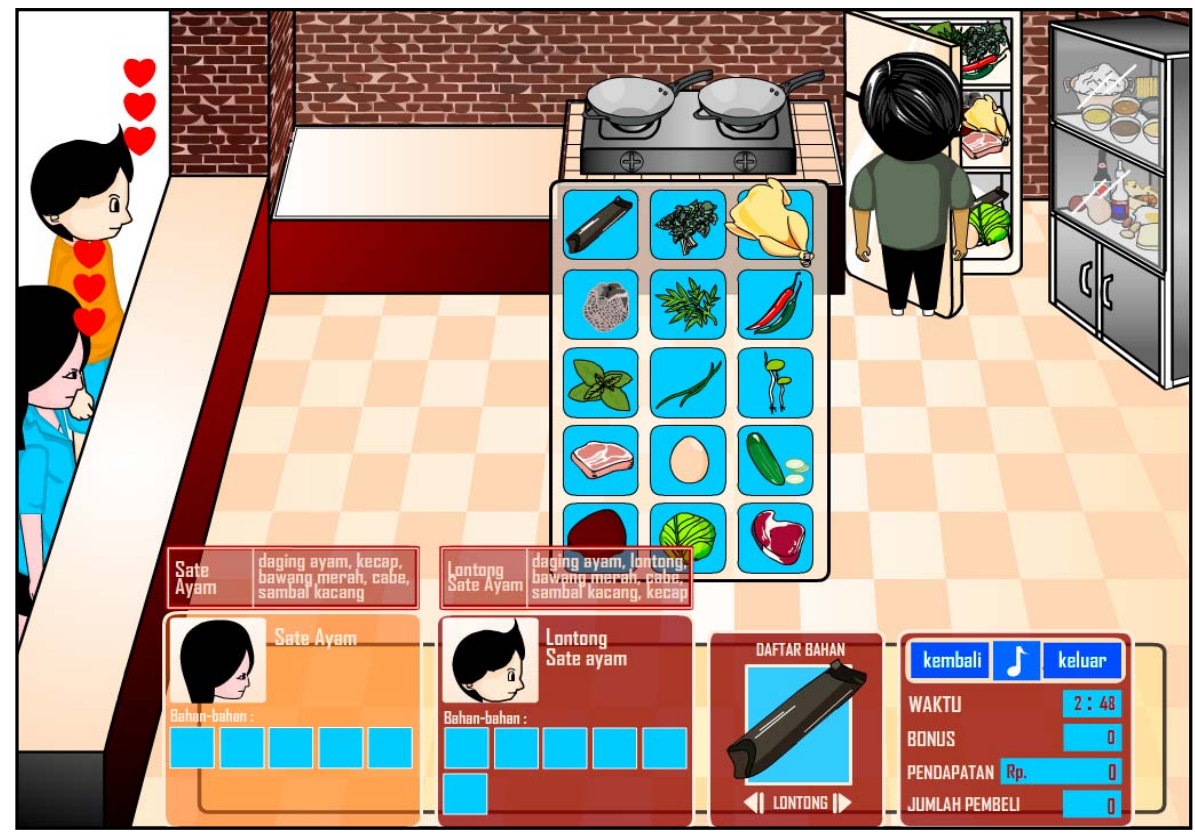

Gambar 5. Tampilan utama ketika game dimulai

Pada gambar 5, panel persegi di kiri bawah menunjukkan pembeli dan jenis pesanan yang di dalamnya terdapat sederet kotak biru untuk menampilkan bahan-bahan yang dipilih. Di atasnya terdapat resep guna membantu pemain. Pemain perlu melakukan koordinasi untuk menggerakkan tokoh utama menggunakan tanda panah pada keyboard dan memilih bahan masakan menggunakan klik mouse. Adanya tanda 3 hati pada pembeli menjadi acuan agar pembeli dilayani dengan cepat. Jika pemain memilih bahan dengan tepat dan cepat, maka pendapatan bertambah sesuai harga makanan yang dipesan dan juga mendapat bonus. Cara bermain ini sudah masuk ke ranah afektif dan kognitif. Secara keseluruhan, tindakan di atas sudah mengandung tiga kecerdasan sekaligus, yakni mengimplementasikan pengetahuan dan pemahaman (kognitif) yang diterima dan direspon (afektif) melalui tindakan menggerakkan tokoh game (psikomotorik) untuk memilih bahan masakan sesuai pesanan pembeli.

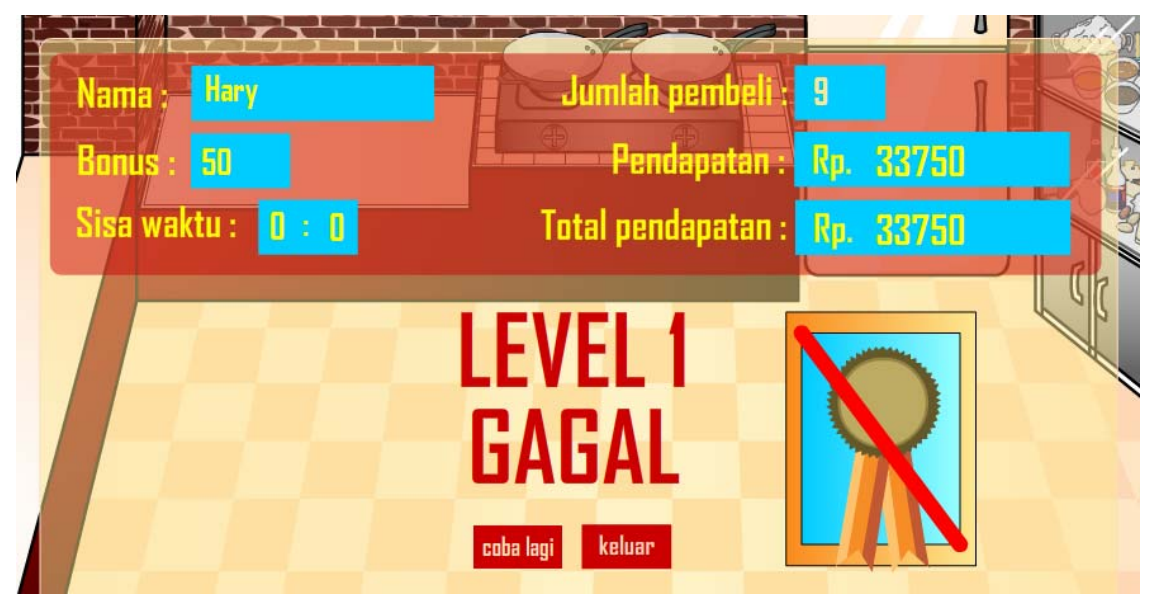

Gambar 6. Reward yang didapatkan pemain tiap level: bonus, pendapatan, dan total pendapatan, serta medali jika mencapai target 
Setiap level yang dilalui pemain, ketika waktu habis akan menuju tampilan reward yang meliputi: bonus, pendapatan, total pendapatan, dan medali. Bonus dihitung melalui sisa waktu dan koin yang berhasil dikumpulkan. Pendapatan merupakan akumulasi dari uang yang dibayarkan pembeli sesuai dengan makanan yang dipesannya. Medali terbagi menjadi 3 jenis, yakni: medali emas jika pendapatan level 1 mencapai > 100 ribu, medali perak jika pendapatan $>75$ ribu dan $<100$ ribu, serta medali perunggu jika pendapatan $>50$ ribu dan $<75$ ribu.

\section{PENUTUP}

\subsection{Kesimpulan}

Semakin dewasa dunia pendidikan ini, aspek afektif dan psikomotorik mulai mendapat perhatian meskipun masih di bawah kognitif. Terkadang anak lebih trampil mempraktikkan sesuatu daripada menghafal sesuatu. Teori dan pemahaman saja tidak cukup, sehingga anak perlu dibekali sikap untuk bisa menerima dan merespon apa yang disampaikan, yang kemudian diimplementasikan dalam tindakan. Melalui permainan, ketiga kecerdasan di atas bisa dieksplorasi bersama. Permainan baik tradisional maupun digital sebenarnya memiliki potensi untuk turut mengembangkan ketiga kecerdasan tersebut. Namun tentunya hal ini tidak lepas dari peran orang tua. Dengan mengangkat konten lokal, anak-anak akan mendapatkan pengetahuan tentang masakan khas Jawa Tengah tidak hanya sekedar namanya, tetapi juga bahan pembuatnya. Anak-anak juga bisa berperan sebagai pembeli yang melayani penjual dengan baik dan komunikatif, sehingga secara tidak langsung membentuk sikap untuk membangun komunikasi dengan orang lain, saling menghormati, serta trampil dalam melakukan suatu pekerjaan baik di sekolah maupun di rumah. Jadi, game simulasi "Warungku" bisa menjadi alternatif bagi orang tua untuk turut mengembangkan ketiga kecerdasan tersebut pada anak.

\subsection{Saran}

Game "Warungku" yang telah dibuat ternyata masih banyak kekurangan. Banyaknya bahan-bahan yang perlu dipelajari membuat pemain cenderung kehilangan fokus. Ditambah lagi menu masakan yang semakin bertambah setiap naik level. Game ini akan lebih baik jika lebih dipersempit konten lokalnya, misal: mengangkat makanan/masakan khas Semarang saja. Semakin maraknya perangkat portable dengan kemampuan hampir dengan setara komputer, game ini akan lebih menarik jika dikembangkan pada smartphone dan tablet agar bisa dimainkan kapan saja dan dimana saja, tidak harus dimainkan di rumah melalui komputer. Selain itu, agar lebih disukai anak-anak, game bisa dibuat lebih simpel tanpa mengurangi nilai lebih dari konten yang diangkat, agar sesuai dengan kapasitas kemampuan kognitif, afektif, serta psikomotorik anak sekolah dasar, sehingga ketiga kecerdasan tersebut benar-benar bisa digali secara optimal. 


\section{DAFTAR PUSTAKA}

[1]http://www.voa-islam.com/read/muslimah/2009/07/25/456/masa-keemasananak/ (diakses: 17 Februari 2014, 04:54 WIB)

[2]http://www.fipumj.net/artikel1679091c5a880faf6fb5e6087eb1b2dc-STRATEGIPEMBELAJARAN-ANAK-USIA-DINI.htmI (diakses: 17 Februari 2014, 04:54 WIB)

[3]Lucy, B. 2009. Mendidik Sesuai Dengan Minat dan Bakat Anak. Jakarta: Tangga Pustaka

[4]Fatonah, S. 2009. Menumbuhkan Kecerdasan Majemuk (Multiple Intelligence) Anak Dengan Mengenal Gaya Belajarnya Dalam Pembelajaran IPA SD. Jurnal AlBidayah, Vol 1[2], h 229-245. Yogyakarta: UIN Sunan Kalijaga

[5]Budiman, L. 2007. Menjadi Orang Tua Idaman: Menyelami Dunia Anak. Jakarta: Kompas

[6]http://badanbahasa.kemdikbud.go.id/kbbi/

[7]Anonim. 2011. Suplemen Bahan Ajar: Unit-4 Sejarah Perkembangan Kurikulum di Indonesia

[8]Hardywinoto dan Setiabudhi. 2003. Anak Unggul Berotak Prima. Jakarta: Gramedia

[9]Harsanto, R. 2007. Pengelolaan Kelas yang Dinamis: Paradigma Baru Pembelajaran Menuju Kompetensi Siswa. Yogyakarta: Kanisius

[10]Depdiknas. 2008. Kamus Besar Bahasa Indonesia. Jakarta: Pusat Bahasa

[11]Sunandar. 2011. Slide Presentasi: Taksonomi Tujuan Instruksional. Semarang: IKIP

[12]Santrock, J.W. 2003. Asdolescence (Perkembangan Remaja, alih bahasa: Adelar, S.B. dan Saragih, S.). Jakarta: Erlangga 